Anna Sokót-Klein*

\title{
Specyfika komunikatu reklamowego
}

\section{ReKLAMA JAKO AKT KOMUNIKACJI}

Leksem reklama posiada niezwykle dużo różnorakich definicji. Wyjaśnienie tego pojęcia zależy bowiem od przyjętej perspektywy badawczej. Inaczej definiuje się reklamę w językoznawstwie, a inaczej w takich dziedzinach, jak socjologia, psychologia czy ekonomia. $Z$ punktu widzenia lingwistyki reklamę można scharakteryzować jako określony akt komunikacji, który ma trzy najważniejsze cele ${ }^{1}$ :

- perlokucyjny (konkretne działanie odbiorcy, które jest rezultatem skuteczności przekazu reklamowego);

- perswazyjny (nakłanianie odbiorcy do podjęcia konkretnego działania, w przypadku reklamy: do zakupu reklamowanego produktu);

- informacyjny (przekazywanie informacji o towarach i usługach).

Definiując reklamę jako akt komunikacji, należy wspomnieć o modelu komunikacji językowej Romana Jacobsona (1989). Reklama bowiem to określony komunikat, który posiada nadawcę i odbiorcę (między rozmówcami musi więc zaistnieć pośredni lub bezpośredni kontakt). Jest on realizowany za pomocą wspólnego dla nadawcy i odbiorcy kodu w określonym kontekście sytuacyjnym. Warto zatrzymać się na chwilę przy tym schemacie i zastanowić nad jego poszczególnymi elementami:

1. Komunikat - w przypadku reklamy to reklamowy przekaz informacyjny, czyli tekst nadawcy skierowany do odbiorcy.

2. Nadawca - nadawcą komunikatu reklamowego, najogólniej rzecz biorąc, jest reklamodawca (nadawca prymarny). Ważniejszy jednak wydaje się

"Dr Anna Sokół-Klein - Uniwersytet Łódzki, Wydział Filologiczny, Katedra Współczesnego Języka Polskiego, al. Kościuszki 65, 90-514 Łódź.

${ }^{1} \mathrm{O}$ celach i funkcjach komunikatu reklamowego m.in. piszą: J. Kall (1995), J. Bralczyk (1996), B. Kwarciak (1997), P. Lewiński (1999), K. Albin (2002), W. Lubaś (2006) i inni. 
nadawca sekundarny/posiłkowy (pośrednik), który występuje w imieniu nadawcy prymarnego, a w samej reklamie ukazuje się jako postać konkretnego bohatera przekazu reklamowego ${ }^{2}$. Może nim być celebryta, ekspert, użytkownik produktu, czy choćby postać animowana.

3. Odbiorca - odbiorcą przekazu reklamowego jest konsument, czyli osoba, która nabywa towary i usługi. Odbiorca reklamy może być bezpośredni, gdy jest nim potencjalny klient, oraz niebezpośredni - nie jest bezpośrednim nabywcą produktu (dzieci, zwierzęta).

4. Kontakt - kontakt między nadawcą a odbiorcą odbywa się za pomocą kanału, czyli „fizycznej przestrzeni, która przewodzi znaki-symbole (dźwięk, pismo, ikony)" (Lubaś 2006: 15). W przypadku przekazu reklamowego są to ${ }^{3}$ :

a) wizualne środki reklamowe (prasa, reklama outdoorowa, środki drukowane czy takie towary, jak próbki, gadżety reklamowe);

b) akustyczne środki reklamowe (reklama radiowa, płyty i kasety reklamowe);

c) audiowizualne środki reklamowe (reklama telewizyjna);

d) inne środki reklamowe (targi, degustacje, wystawy).

5. Kod - język oraz kompetencja socjolingwistyczna (umiejętność społecznego zachowania językowego), które są wspólne nadawcy i odbiorcy (Lubaś 2006: 15). W przekazie reklamowym można wyróżnić takie warstwy kodowe, jak kody językowe (środki językowe oraz parajęzykowe foniczne i graficzne) i kody wizualne (środki figuralne, czyli obrazy, ikony i symbole oraz środki niefiguralne, czyli kolor czy sama kompozycja tekstu $)^{4}$.

6. Kontekst - to sytuacja, w której dokonuje się proces komunikacji, czyli jej czas i miejsce, a także role, jakie odgrywają nadawcy i odbiorcy w komunikacji oraz przyjęta przez nich hierarchia wartości.

\section{WYGLĄD I BUDOWA PRZEKAZU REKLAMOWEGO}

Każdy dobry przekaz reklamowy powinien realizować schemat oddziaływania, jakim jest AIDA. Litery tego akronimu oznaczają:

A - attention (uwaga),

I - interest (zainteresowanie),

$\mathrm{D}$ - desire (pożądanie),

$\mathrm{A}-\operatorname{action}(\mathrm{działanie})$.

${ }^{2}$ Por. Wiśniewska, Miczmańska 2011: 134; Lewiński 1999: 40.

${ }^{3}$ Rodzaje kanałów reklamowych cytuję za: Lewiński 1999: 30-32.

${ }^{4}$ Rodzaje kodów występujących w przekazie reklamowym przytaczam za: Lewiński 1999: 32 . 
Przekaz reklamowy musi zatem być na tyle oryginalny, by zwrócić uwagę potencjalnego konsumenta, zainteresować go reklamowanym produktem, wzbudzić chęć posiadania tego produktu, a w efekcie nakłonić klienta do dokonania konkretnego zakupu. Przyciaggać z pewnością mogą elementy wizualne. W przypadku reklamy prasowej, outdoorowej czy telewizyjnej nieodłącznym elementem jest obraz, który wraz z tekstem powinien stanowić harmonijną całość. W reklamie prasowej czy outdoorowej na pierwszym planie zdjęcia najczęściej usytuowany jest produkt. Jest on wyrazisty, atrakcyjny i posiada intensywną kolorystykę, gdyż - jak zauważa Stanisław Kuśmierski „Nadrzędnym nakazem w reklamie jest podwyższenie atrakcyjności prezentowanych produktów" (2000: 140). Ponadto na zdjęciu można często zauważyć także efekt działania produktu: w przypadku kostki rosołowej jest to aromatyczna zupa, a w przypadku kosmetyku - piękne i idealne ciało. Niezwykle ważne jest również tlo obrazu, które mimo że jest zamazane, może wzmacniać wartość całego przekazu. Jeśli bowiem lekarz reklamuje lek, dobrze jeśli znajdzie się za nim biblioteczka z książkami, która podkreśli jego wiedzę. Z kolei kucharz najczęściej promuje swoje produkty w nowej, czystej i wypełnionej świeżymi przyprawami kuchni, a polityk, przekonując wyborców do oddania na niego głosu, zazwyczaj znajduje się na tle flagi narodowej lub godła. Istotną rolę odgrywa też światto, które uwydatnia produkt spośród wielu innych znajdujących się na ilustracji. W przypadku reklamy telewizyjnej światło zazwyczaj znajduje się w ostatnich sekundach trwania filmu. Wtedy to produkt występuje w wersji statycznej i jest oświetlony. Światło symbolizuje też coś pozytywnego, dlatego w reklamie leków czy suplementów diety nakierowane jest na osobę zdrową, która jako jedyna jest kolorowa i „wyraźna”. W przypadku reklamy czarno-białej światło może pełnić symboliczną funkcję, czego przykładem jest reklama produktów firmy Polar. Na zdjęciu reklamy widnieje bowiem siedząca na podłodze kobieta, której ciało skierowane jest w stronę lodówki. $Z$ kolei od produktu bije jasne i intensywne światło. Kobieta wygląda jakby modliła się do bóstwa. Inna reklama pokazuje kobiece ciało, które wciaggane jest przez światło okapu. Sytuacja ukazana na zdjęciu przypomina statek kosmiczny, którego moc światła może wciągnąć na pokład każdego człowieka. W przypadku elementów wizualnych ważna jest też kolorystyka. Każda barwa ma bowiem inny symbol i przywołuje odmienne emocje ${ }^{6}$. Kolor czerwony kojarzony jest z czymś gorącym: może więc to być gorące uczucie (reklama portalu randkowego) lub pożar (reklama leków przeciw zapaleniu

${ }^{5} \mathrm{~W}$ popularnej reklamie leku Rutinoscorbin jeden $\mathrm{z}$ bohaterów mówi do przeziębionej osoby: „Coś niewyraźnie dziś wyglądasz”.

${ }^{6} \mathrm{O}$ symbolice kolorów można przeczytać w jednej z książek Ryszarda Tokarskiego (2004). 
płuc czy gardła). Barwa zielona kojarzy się ze spokojem, więc dominuje wtedy, gdy nadawca reklamuje produkt spożywczy związany z naturą (reklama mleka, sera, owoców, wody źródlanej). Istnieją również kolory, które są znakiem fabrycznym marki. W przypadku np. słodyczy kolor fioletowy został opatentowany przez producentów czekolady Milka. Z kolei żółty „należy” do herbaty Lipton, a jasnoczerwony do napoju Coca-Cola. Trzeba pamiętać o tym, że barwa nie może odstraszać konsumenta. Kolor czarny nie powinien więc znajdować się na opakowaniu paczki papierosów, gdyż wtedy mógłby kojarzyć się ze szkodliwymi substancjami smolistymi. Niektórzy producenci pamiętają o tym, że jeśli opakowanie jest atrakcyjne, może zostać z klientem dłużej niż sam produkt. Konsumenci wykorzystują bowiem pudełka po herbatach czy słodyczach do przechowywania różnych akcesoriów domowych, a wtedy i pamięć o marce pozostaje dłużej w umysłach klientów.

Oprócz elementów wizualnych niezwykle ważne w reklamie są też takie składniki, jak: slogan, nagłówek i sam tekst reklamowy.

Nagłówek to pierwszy wiersz reklamy, który jako skondensowany tekst stanowi wstęp do treści całego tekstu reklamowego. Jego głównym zadaniem jest pobudzenie ciekawości i wyobraźni odbiorcy. Nagłówek powinien być zatem pomysłowy i niebanalny - zarówno treściowo, jak i formalnie. Jacek Kall (1995: 95) wskazuje na kilka kategorii nagłówków. Do najpopularniejszych należą:

- nagtówki wskazujace na nowość - chyba najmniej oryginalna forma nagłówka. W większości reklam można zobaczyć, że ich pierwszy wers zaczyna się właśnie od nagłówka NOWOŚĆ;

- nagłówek emocjonalny - nagłówek, który silnie oddziałuje na emocje konsumenta. Do najpopularniejszych można zaliczyć te, które wzbudzają strach przed utratą zdrowia odbiorcy, np.: Czy obawiasz się o swój wzrok? (reklama preparatu na oczy Doppelherz ${ }^{\circledR}$ aktiv) ${ }^{7}$;

- nagtówek sugerujacy - to nagłówek, który „podpowiada” odbiorcy podjęcie konkretnych działań, np.: Zastosuj Lactovaginal;

- nagtówek typu „chwalmy się” - jak twierdzi Jacek Kall: „Takie nagłówki moga przyjmować postać pozbawionego uroku, otwartego «chwalipięctwa» lub też być wyrazem dumy z produktu" (1995: 96). Przykładem mogą tu być nagłówki typu: Numer 1, Jedyny w swoim rodzaju, Najlepszy z najlepszych itp., które stosunkowo często pojawiają się we wszystkich typach reklamy.

Slogan można podzielić na slogan firmowy i hasło reklamowe. Slogany firmowe reprezentują strategię marketingową firmy i przekazują jej trwałe

${ }^{7}$ Wszystkie przykłady (czy to nagłówków, czy sloganów) pochodzą z reklam umieszczonych w kolorowych czasopismach z 2013 r. 
przesłanie ${ }^{8}$. W przeciwieństwie do haseł reklamowych dotyczą więc całej firmy, a nie jej pojedynczego wytworu, czyli konkretnego produktu. Dlatego też najczęściej występują przy logo firmy, tworząc z jej nazwą spójny komunikat, np.: Dzis zmienia sie z ORANGE; AVON - the company for women; Nike Just do it; Wedel-fabryka przyjemnosici; Winiary - dobre pomysty, dobry smak; L'Oreal. Ponieważ jestem tego warta itd. Z kolei hasto reklamowe, w przeciwieństwie do sloganu firmowego, może przyjąć nieco bardziej opisową formę. Im jednak jest krótsze, tym łatwiej zapamiętywane przez odbiorców. Najważniejsze jest bowiem to, by zawładnąć jakimś wyrazem w świadomości potencjalnych klientów, a nawet by „wypalić” hasło w ich umyśle, które będzie kojarzyło się z jednym i konkretnym produktem' . Jacek H. Kołodziej (2002: 97-107) umieszcza slogan ${ }^{10} \mathrm{w}$ kategoriach definicji perswazyjnej. Dla badacza slogan to najkrótsza definicja marki ( $\mathrm{X}$ to $\mathrm{K}$ ), będąca przedstawieniem korzyści, „które w związku z nabyciem marki obiecuje nadawca komunikatu” (tamże: 99). Autor wyróżnia trzy rodzaje definicji charakteryzujących markę (tamże: 101-103):

- definicje klasyczne, które skupione są na jakiejś cesze wyróżniającej dany produkt spośród innych, np.: Usta petne za jednym pociagnięciem (L’Oreal); Red Bull doda ci skrzydet...; Sakramencko dobre piwo (piwo Tatry) itd.;

- normy instrumentalne, w których opisany jest cel i droga, jaką trzeba przebyć, by ten cel osiągnąć, np.: Pij mleko (droga), będziesz wielki (cel); Kup Rafaello (droga) - wygraj bon jubilerski o wartości 5000 zt (cel) itd.;

- normy właściwe, w których wspomniany jest tylko cel związany z dokonaniem zakupu produktu, np.: Wybierz Seni Lady; Odkryj idealny sposób na gtęboko nawilżona i promienna skórę (krem Nivea).

Tekst reklamowy to najdłuższa i jednocześnie najrzadziej czytana część reklamy. Jacek Kall wspomina nawet o tym, że „Treść przeciętnego ogłoszenia reklamowego (body copy) w magazynach konsumenckich jest czytana przez 5\% czytelników, w magazynach specjalistycznych - rzadko kiedy przez więcej niż 10\%” (1995: 97). Zadaniem tekstu reklamowego jest dostarczenie odbiorcy szczegółowych informacji na temat produktu. Jeśli więc klient nie jest zainteresowany reklamowaną usługą/produktem, istnieje duże prawdopodobieństwo, że nie zapozna się z treścią całego tekstu. W treści reklamy

${ }^{8}$ Żywotność sloganu firmowego jest więc znacznie dłuższa niż hasła reklamowego. Por. też artykuł umieszczony na portalu wiedzy dla menedżerów nf.pl (http://kadry.nf.pl/ Artykul/13730/Slogany-firmowe-Wspracie-wyroznienia-marki-firmy/marka-firmy-misja-firmy-slogany-firmowe-wizja-firmy).

${ }^{9}$ Por. Kołodziej 2002: 98.

${ }^{10}$ Badacz nie dokonuje tu podziału sloganu na firmowy i hasło reklamowe. Rozumie slogan ogólnie jako krótką wypowiedź charakteryzującą markę. 
nadawca skoncentrowany jest na wymienieniu korzyści, które może osiągnąć klient, dokonując zakupu towaru. Mogą być one podane w postaci wyliczeń, opowiadania, dialogu pomiędzy bohaterami reklamy, a nawet - w przypadku reklamy prasowej - listu reklamodawcy skierowanego wprost do czytelnika. Język tego najdłuższego składnika reklamy głównie zależy od typu odbiorcy i rodzaju reklamowanego produktu. Gdy adresatem jest osoba młoda, treść reklamy najczęściej zawiera potocyzmy oraz wyrazy zapożyczone $\mathrm{z}$ języka angielskiego. $Z$ kolei w przypadku reklam produktów farmaceutycznych nadawca komunikatu stosuje dużą liczbę terminów - zarówno polskich, jak i obcych. Taka reklama utrzymana jest więc głównie w stylu naukowym ${ }^{11}$. Mówiąc o języku reklamy, nie sposób nie wspomnieć o funkcji poszczególnych części mowy pojawiających się w tekstach reklamowych, a także o takich kategoriach gramatycznych, jak czas i tryb obecnych w tekście czasowników czy rodzaj, w którym występują nazwy produktów. Ponieważ to zagadnienie wymagałoby odrębnego opracowania, pozostaje mi odesłać Czytelnika do książki Jerzego Bralczyka zatytułowanej Język na sprzedaż (1996) ${ }^{12}$.

\section{RODZAJE REKLAM}

Stanisław Kuśmierski dokonał w swojej książce podziału reklam na te, które mają duży zasięg (above the line) oraz na te o niewielkim zasięgu (below the line $)^{13}$. Do pierwszych zalicza: reklamę telewizyjną, prasową, radiową i outdoorową, natomiast do drugich: list reklamowy, plakat, ulotkę, reklamę $\mathrm{w}$ prasie specjalistycznej oraz teleshoping. $\mathrm{W}$ artykule zostaną krótko scharakteryzowane trzy najbardziej popularne typy reklam o dużym zasięgu.

\section{Reklama prasowa}

Jako że zaletą gazet jest ich trwałość, reklama prasowa może być bardziej zapamiętana przez konsumenta niż reklama telewizyjna, która ze względu na jej dużą częstotliwość jest uznawana za najbardziej natrętną, a telewizyjne bloki reklamowe są dobrą okazją dla odbiorcy do tego, by przygotować posiłek, skorzystać z toalety czy zobaczyć fragment programu na innym kanale. $Z$ kolei do reklamy prasowej zawsze można wrócić, kartkując ponownie ulubione

${ }^{11}$ O stylach w reklamie można przeczytać w książce Władysława Lubasia (2006: 203-214).

${ }^{12}$ Szczególnie warto zwrócić uwagę na rozdział zatytułowany Gramatyka reklamy (s. 84-114).

${ }^{13}$ Kuśmierski 2000: 87-88. 
czasopismo $^{14}$. Najważniejszym elementem reklamy prasowej jest tekst, dlatego jeśli reklamodawca pragnie przekazać konsumentowi dużo ważnych informacji o produkcie, powinien wybrać właśnie to medium. Słuchając reklamy radiowej czy oglądając reklamę telewizyjną, odbiorca nie jest w stanie zapamiętać takiej ilości informacji, jak w przypadku spokojnej lektury czasopism. W każdym czasopiśmie/gazecie codziennej czytelnik ma jednak do czynienia z niezwykle dużą liczbą reklam. Aby więc reklama była zauważalna, powinna mieć jak największe rozmiary. Ponadto duże reklamy mogą kojarzyć się czytelnikom z potęgą samego reklamodawcy. Jak zauważa Stanisław Kuśmierski: „Badania socjologiczne dowiodły, że czytelnicy rozmiary reklam utożsamiają z rozmiarami przedsiębiorstwa. Ludzie myślą, że tylko duże, prężne firmy stać na taki wysiłek finansowy” (1995: 84). Duże reklamy prasowe, oprócz tego, że często zajmują całą stronę, mogą być też kilkustronicowe. Przykładem może być choćby reklama jogurtu Jogobella, która w wielu czasopismach została umieszczona na trzech prawych stronach, choć dopiero jej ostatnia część pokazała czytelnikowi, o jaki produkt chodzi nadawcy.
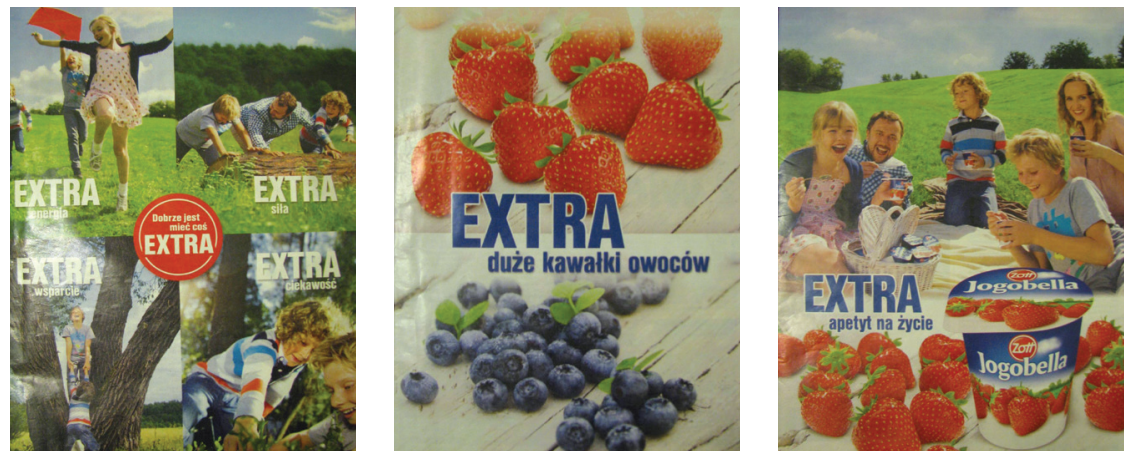

Rys. 1. Reklama prasowa jogurtu Jogobella

Źródło: „Tele Tydzień” 2012, nr 11, s. 13, 15, 17

Warto przy okazji wspomnieć o tym, że reklama prasowa zawsze znajduje się na prawej stronie czasopisma. Takie umieszczenie komunikatu nie jest przypadkowe. Marian Szulc twierdzi, że

psycholodzy, szczególnie w Stanach Zjednoczonych, przeprowadzili setki badań mechanizmu odbioru prasy - co zresztą było istotne dla firm wykupujących reklamy [...]. Obserwacje $z$ udziałem ukrytej kamery pozwalają przyjrzeć się nawet nieświadomym zachowaniom czytelników. Stąd wiadomo, że [...] z dwu sąsiadujących stronic większość czytelników wpierw spojrzy na prawą (Szulc 2000: 273).

${ }^{14}$ Jacek Kall podkreśla, że czasopisma mogą być czytane przez kobiety nawet pięć miesięcy od daty ukazania się danego numeru. Patrz: Kall 1995: 89. 
W przypadku reklamy prasowej ważne jest również odpowiednie rozmieszczenie wszystkich jej elementów. Najważniejszy składnik powinien być najbardziej wyeksponowany ${ }^{15}$. Istotny jest każdy szczegól: krój, rozmiar i kolor czcionki, a także wielkość obrazu oraz jej pozostałych elementów. Wszystkie składniki reklamy powinny stanowić uporządkowaną i harmonijną całość ${ }^{16}$.

\section{Reklama radiowa}

Reklama radiowa, jak zauważa Jacek Kall (1995: 118), wymieniana jest - zaraz po reklamie telewizyjnej i prasowej - na trzecim miejscu w skali ważności. Największym jej minusem może być brak przekazu wizualnego, co uniemożliwia pokazanie działania produktu czy choćby jego opakowania. $Z$ drugiej strony, w przeciwieństwie do reklamy prasowej, wykorzystuje dźwięk, za pomocą którego oddawany jest każdy element rzeczywistości. Jeśli więc bohaterem reklamy jest biegnąca do sklepu kobieta, słychać stukot jej butów; jeśli preparat przeciwko insektom, odbiorca usłyszy brzęczenie owadów, jeśli zaś akcja reklamy toczy się w restauracji, słychać gwar rozmawiających ludzi, dźwięk sztućców czy odgłosy wydawane w czasie jedzenia i picia. Ponadto, brzmienie ludzkiego głosu nadaje słowom emocjonalny charakter, czego nie może zapewnić odbiorcy przekaz wizualny. Nie bez kozery więc reklama radiowa nazywana bywa „teatrem wyobraźni” (tamże: 119), gdyż właśnie radio jest takim medium, które najbardziej pobudza wyobraźnię odbiorcy.

Radio, jako medium wykorzystujące tylko dźwięk, ma jednak sporo ograniczeń. Reklamodawca, umieszczając w nim swoją reklamę, powinien zrezygnować z przekazu, który zawierałby dużą ilość informacji. Odbiorca, słuchając piętnastosekundowego spotu reklamowego, nie będzie bowiem w stanie zapamiętać wielu danych, które chce mu przekazać nadawca. Najważniejsze informacje, które powinny się znaleźć w reklamie radiowej to: nazwa produktu (najlepiej jeśli w reklamie jest wielokrotnie powtórzona), zakres jego działania oraz adres strony internetowej, na której konsument znajdzie pozostałe wiadomości o produkcie/usłudze razem z danymi teleadresowymi. $\mathrm{Na}$ niekorzyść reklamy radiowej działa również to, że samo medium, jakim

${ }^{15}$ Do stałych składników reklamy prasowej należą logo i adres reklamowanej firmy/instytucji, w której znajduje się produkt. Pozostałe elementy nie są obligatoryjne.

${ }^{16}$ Najczęstszy rozkład elementów reklamy to: ilustracja, pod którą znajduje się nagłówek, a następnie treść oraz slogan i logo. Logo produktu zazwyczaj ma swoje stałe miejsce - znajduje się, najczęściej razem ze sloganem firmowym, w prawym dolnym rogu. $\mathrm{Na}$ to bowiem miejsce kieruje swój wzrok czytelnik, który przerzuca kolejną stronę czasopisma. 
jest radio, charakteryzuje się stosunkowo niskim prestiżem. Większą popularnością cieszy się telewizja, choć w godzinach 8:00-16:00 to właśnie radio „ma swoje pięć minut”. Jest to bowiem czas pracy przeciętnego Polaka, który w swoim biurze słucha właśnie radia. Reklama radiowa sprawdza się także w przypadku kierowców, stąd nierzadko można w radiu usłyszeć komunikaty promujące stacje benzynowe czy akcesoria samochodowe. Istotną zaletą radia jest również to, że w XXI w. mamy możliwość słuchania go niemal wszędzie (choćby za pośrednictwem telefonów komórkowych), co może wpływać na końcową decyzję związaną z zakupem produktu. Jak bowiem zauważa Bogusław Kwarciak: „Zgodnie z psychologicznym prawem świeżości, klient w miejscu sprzedaży najłatwiej przypomina sobie informacje o produktach, które dotarły do niego na samym końcu, a więc jako ostatnie. Na dalszy plan zostają zepchnięte na przykład telewizyjne spoty z poprzedniego dnia" (1997: 178). Niemniej istotną zaletą reklamy radiowej jest krótki czas jej produkcji ${ }^{17}$ oraz stosunkowo niskie koszty ${ }^{18}$.

Każda reklama radiowa zazwyczaj składa się z trzech etapów: wprowadzenia, prezentacji zalet produktu i zakończenia. Wstęp reklamy/wprowadzenie ma za zadanie skutecznie przyciągnąć uwagę odbiorcy, tak by słuchacz nie chciał zmienić stacji na inną. Reklama może więc zaczynać się jak serwis informacyjny lub piosenka, która przerywa radiową listę przebojów. Tym sposobem słuchacz początkowo nie zdaje sobie sprawy z tego, że ma do czynienia z reklamą. Ważne jest również to, by we wprowadzeniu, które trwa około trzech sekund, nie znajdowały się żadne ważne informacje, gdyż na tym etapie reklamy nie zostaną przez słuchacza zapamiętane. Drugi etap reklamy radiowej, czyli prezentacja zalet, może przybierać różne formy: może to być rymowanka, skecz, piosenka, dialog czy wywiad. W końcu ostatnia faza reklamy to zakończenie, w którym nadawca zaprasza klienta do zakupu produktu bądź usługi, podaje adres strony internetowej, numer telefonu (jeśli jest łatwy do zapamiętania) oraz, niekiedy, slogan.

Ostatnią rzeczą, o której należy wspomnieć, charakteryzując reklamę radiową, są rodzaje promocji, z którymi słuchacz może się spotkać w radiu. Wiesława Kubaszewska i Marcin Hermanowski (2008) wyróżniają sześć form promocji w radiu: ogłoszenie drobne (najczęściej czytane przez prowadzącego program), ogłoszenie reklamowe (forma pośrednia pomiędzy drobnym ogłoszeniem a spotem reklamowym), spot reklamowy (występuje

${ }^{17}$ Czas przygotowania i umieszczenia reklamy w radiu może się zamknąć w ciągu jednego dnia.

${ }^{18}$ Jeśli jednak radio jest jedynym medium, w którym umieszcza się określoną reklamę, to jej skuteczność zależy od liczby powtórzeń komunikatu promocyjnego w wielu różnych stacjach. Wtedy emisja takiej reklamy staje się droga. 
w formie scenki rodzajowej, dialogu, piosenki, skeczu czy wywiadu), audycja reklamowa (wywiad lub wypowiedź ekspertów), program sponsorowany (sponsor audycji w zamian otrzymuje dżingiel sponsorski, który wyemitowany jest na początku oraz na końcu programu), konkurs (podobnie jak w przypadku programu sponsorowanego - sponsor nagród otrzymuje krótki dżingiel sponsorski).

\section{Reklama telewizyjna}

Reklama telewizyjna, dzięki połączeniu obrazu, słów i dźwięku, najlepiej potrafi przyciągać i zatrzymać uwagę odbiorcy. Ponadto, w przeciwieństwie do reklamy prasowej i radiowej, może zademonstrować działanie produktu. Ważny jest w niej zatem ruch, obraz i kolor. Nie musi zawierać dużo słów, gdyż telewidz ją ogląda, a nie czyta. Jacek Kall (1995: 109) zwraca uwagę na to, że skomplikowane obrazy czy szybkie tempo filmu wymagają niewiele słów. W innym wypadku percepcja reklamy może być zakłócona. Istotny jest również dźwięk, bez którego reklama telewizyjna nie miałaby tak silnego wpływu na odbiorcę. Dźwięk wprowadza odpowiedni nastrój, nasuwa określone skojarzenia i oddziałuje na emocje odbiorcy. Reklama niekiedy wykorzystuje znany już przebój (ostatnia reklama pieluszek Dada wykorzystała refren piosenki Formacji Nieżywych Schabuff pt. Da da da) lub go modyfikuje (reklama produktów Bonduelle stworzyła nowy tekst do znanej piosenki You're the one that I want), a innym razem nowa melodia tworzona jest na potrzeby reklamy telewizyjnej konkretnego produktu. Tak było choćby z reklamą czekoladek Merci, której piosenka stała się na tyle popularna, że chyba każdemu kojarzy się z reklamowanym produktem.

Telewizja jako medium cieszy się dużym prestiżem, więc i reklama telewizyjna ma szerokie grono odbiorców. $Z$ drugiej jednak strony reklama telewizyjna bywa uznawana za najbardziej natrętną. Traktuje się ją jak „«zło konieczne», które trzeba przeczekać, zanim zacznie się prognoza pogody lub film” (Kall 1995: 104). Najlepszą pozycję w całym bloku reklamowym ma więc pierwsza reklama, gdyż czas jej trwania pokrywa się z procesem wstawania widza $z$ kanapy bądź krzesła oraz momentem przejścia do innego pomieszczenia. Nie gorszą pozycję ma również ostatnia lub przedostatnia reklama bloku reklamowego, gdyż jest to czas, w którym widz „wraca” do stacji z oglądanym filmem lub, jeśli nie przełączył kanału, zaczyna skupiać swoją uwagę na tym, co jest w telewizji, gdyż wie (mniej więcej), jak długo trwa określony blok reklamowy ${ }^{19}$. Istotne jest również to, by umieścić

${ }^{19} \mathrm{~J}$. Kall uważa, że ostatnia reklama zajmuje najgorszą pozycję w całym bloku reklamowym, gdyż wtedy uwaga widza jest najmniejsza (1995: 105). 
reklamę w odpowiednim bloku reklamowym. Można więc zaobserwować, że pieluszki bądź zabawki występują w bloku reklamowym, który znajduje się przed wieczorynką i wiadomościami, piwo najczęściej reklamowane jest przed meczem piłkarskim, a akcesoria domowe czy produkty kulinarne w trakcie trwania telewizji śniadaniowej, której odbiorcami najczęściej są gospodynie domowe.

Dużą wadą reklamy telewizyjnej jest również czas, który trzeba poświęcić na jej przygotowanie. Ułożenie scenariusza, wybranie aktorów, zgromadzenie określonych rekwizytów, znalezienie odpowiedniego miejsca, samo sfilmowanie reklamy, prace nad montażem i w końcu emisja mogą zająć ponad dwa miesiące. W związku z tym reklama telewizyjna jest bardzo droga, więc nie każdego reklamodawcę na nią stać.

Charakteryzując reklamę telewizyjną, warto również wspomnieć o jej formach. Jacek Kall (1995: 110-116) wyróżnia sześć podstawowych form reklamy telewizyjnej ${ }^{20}$ :

- demonstracja działania - działanie reklamowanego produktu najczęściej pokazywane jest równolegle z działaniem innego, gorszego wyrobu. Do niedawna w polskiej reklamie porównawczej nadawca wymieniał tylko nazwę reklamowanego towaru, nazywając ten drugi (gorszy) „Zwykłym”. Obecnie coraz częściej można spotkać się z sytuacją, w której reklamodawca wspomina nazwę drugiego konkurującego produktu. Tak dzieje się choćby w przypadku reklam sieci telefonicznych;

- „kawałek życia” - reklamy o tej nazwie funkcjonują według schematu: problem (plama, ból głowy, brak pieniędzy) - rozwiązanie (postać, która przypadkiem ma przy sobie odplamiacz, tabletkę przeciwbólową lub numer telefonu do doradcy finansowego) - zadowolenie dzięki rozwiązanemu problemowi;

- rekomendacje - polecać dany produkt może zarówno celebryta, ekspert, jak i każdy użytkownik. Ważne jest jednak, by określony towar rekomendowała osoba będąca specjalistą w branży, z której pochodzi produkt. Mało wiarygodna byłaby bowiem reklama, w której (przykładowo) prof. Jan Miodek zachęcałby do kupna okien. Istnieją jednak osoby, które przez specyfikę wykonywanego zawodu nie powinny występować w reklamach. Są to m.in. dziennikarze prowadzący serwisy informacyjne. Ze względu na to, że w codziennych programach mówią o prawdziwych wydarzeniach, odbiorca może traktować ich komunikat reklamowy jako czystą, pozbawioną elementów perswazyjno-manipulacyjnych, prawdę ${ }^{21}$;

\footnotetext{
${ }^{20}$ Przykłady reklam telewizyjnych pochodzą z lat 2005-2013.

${ }^{21}$ Por. Sarelo 2000: 151-169.
} 
- styl życia - reklama skoncentrowana jest na bohaterze, który prowadzi swobodny i radosny styl życia, a codziennym towarzyszem postaci jest reklamowany produkt (napój, guma do żucia, kosmetyki, słodycze itd.);

- humor - reklamodawca musi mieć świadomość tego, że zaprezentowany w reklamie rodzaj humoru może nie być zrozumiany przez wszystkich odbiorców. Podobna sytuacja miała miejsce w przypadku reklamy sieci telefonii komórkowej Plus. Specyficzny humor zaprezentowany przez kabaret Mumio nie przez każdego telewidza został zaakceptowany i zrozumiany;

- animacja - wykorzystywana jest nie tylko do reklamy produktów dla dzieci. Animację stosuje się także wtedy, gdy nadawca reklamy pragnie przedstawić sytuację nierealną (reklama napoju Red Bull, w której główny bohater lata czy reklama serka Danio, w której głównym bohaterem jest Mały Głód), niemożliwą do zademonstrowania (sposób działania leku w organizmie człowieka) lub skomplikowaną technicznie.

\section{REKLAMA JAKO PRZEKAZ PERSWAZYJNO-MANIPULACYJNY}

By móc pisać o perswazyjnym czy manipulacyjnym charakterze przekazu reklamowego, należałoby wyjaśnić, czym jest perswazja i manipulacja. Prac na ten temat powstało jednak niezwykle dużo ${ }^{22}$ i nie sposób w krótkim artykule przytoczyć wszystkich ustaleń. O wielości stanowisk badaczy (szczególnie dotyczących pojęcia, jakim jest perswazja) świadczy choćby fragment wypowiedzi redaktorów tomu pokonferencyjnego zatytułowanego Język perswazji publicznej, którzy we wstępie zaznaczają, że

Zawiedzie się ten, kto będzie chciał sięgnąć po tę książkę po to, by uzyskać jednoznaczną odpowiedź na pytanie, czym jest perswazja językowa. Różnice stanowisk $\mathrm{w}$ rozumieniu kluczowego pojęcia zaznaczyły się bowiem już pierwszego dnia konferencji i wraz z rozwojem dyskusji stawały się coraz wyraźniejsze (Mosiołek-Kłosińska, Zgółka 2003: 5).

Nie wdając się więc w zawiłe dyskusje na temat tego, co można uznać za perswazję, a co nią nie jest, najogólniej można stwierdzić, że perswazja ,jest

22 O perswazji i manipulacji pisali m.in.: S. Barańczak (1983),J.Puzynina (1992: 203-223), M. Karwat (1999), J. Bralczyk (2000: 244-250), D. Kopertowska (2000: 231-237), A. Lewicki i P. Nowak (2000: 34-42), P. Lewiński (2001: 285-293), W. Pisarek (2003: 9-17), M. Korolko (2003), W. Lubaś (2006), A. Awdiejew (2004: 71-80), I. Kamińska-Szmaj (2003: 77-79; 2004: 13-27), J. Warchala (2004: 41-60), A. i B. Kudrowie (2004: 91-99), P. Nowak (2004: 137-150), K. Michalewski (1999: 63-69; 2004: 187-197), M. Kita (2004: 199-210), P. Krzyżanowski (2004: 277-282), A. Batko (2005), G. Habrajska (2005: 91-121), M. Tokarz (2006), E. Szkudlarek-Śmiechowicz (2007: 299-307), A. Sokół i B. Kudra (2008: 365-373). 
procesem komunikacyjnym mającym na celu wywarcie wpływu na sposób postrzegania świata przez odbiorcę (zmianę lub modyfikację jego postaw, poglądów, wierzeń, przekonań, sądów) w celu osiągnięcia określonych efektów perlokucyjnych, przy czym odbiorca musi dysponować wolnością wyboru" (Lewiński 2001: 292). Jak dodają Barbara i Andrzej Kudrowie (2004: 95), perswazja, w przeciwieństwie do manipulacji, to jawne oddziaływanie na odbiorcę. Inaczej jest $\mathrm{z}$ manipulacją, którą wspomniani badacze definiują jako „ukryty, zakamuflowany sposób narzucania poglądów, postaw, wartości i decyzji jednostce, który pozbawia ją świadomości tego narzucania, nie daje możliwości innych rozwiązań danego problemu czy też swobodnego wyboru - przez wywieranie określonej (np. psychicznej, społecznej) presji” (Kudrowie 2004: 93). Manipulację opisuje się zarówno w kontekście działań społecznych $^{23}$, definiując ją jako „nieuczciwe kierowanie zachowaniami ludzi”, jak również w odniesieniu do języka, jako sposób „wykorzystania środków językowych do ukrytego i podstępnego wywierania wpływu na ludzi” (Kamińska-Szmaj 2004: 23). W przekazach reklamowych niezwykle często mamy do czynienia z zakamuflowanym sposobem wpływania na odbiorcę. Nadawca, zachęcając klienta do zakupu określonego produktu, wykorzystuje bowiem takie techniki wpływu, jak ${ }^{24}$ :

- reguła wzajemności - jej celem jest wywołanie wśród klientów poczucia zobowiązania (zasada „daję i zabieram”; Cialdini 2004: 39). Przykładem mogą tu być darmowe próbki dołączone do reklamy prasowej, stałe informowanie klientów o „wyjątkowych” i specjalnie przygotowanych dla nich promocjach czy przesyłanie im SMS-ów/kartek z życzeniami świątecznymi. Takie zachowania nadawcy wywołują u odbiorcy chęć odwzajemnienia się za ofiarowane mu prezenty czy ustępstwa;

- reguła zaangażowania i konsekwencji - występuje najczęściej w bezpośredniej relacji z klientem, gdyż wtedy nadawca może wymusić na odbiorcy przyjęcie określonego stanowiska/obietnicy. Jeśli więc odbiorca zadeklaruje, że warto mieć sugerowany przez nadawcę produkt, musi być w swojej decyzji konsekwentny;

- reguła społecznego dowodu słuszności - zasada ta głosi, że jakieś postępowanie jest poprawne tylko wtedy, gdy inni też tak postępują. Zachowanie innych ludzi jest tu więc kluczowe przy podejmowaniu własnych

${ }^{23}$ Część badaczy (J. Warchala 2004: 41-60; P. Krzyżanowski 2004: 277-282) zwraca uwagę na to, że manipulacja przede wszystkim ma naturę psychologiczną, a nie językową.

${ }^{24}$ Krótki opis narzędzi wpływu społecznego, oprócz zebranych przeze mnie przykładów, przedstawiam za R. Cialdinim (2004). Więcej na ten temat w skrypcie pisze E. Olejniczak $\mathrm{w}$ artykule Wywieranie wptywu w komunikacji masowej. 
decyzji. W reklamie regułę tę wykorzystuje się, pokazując grupę osób użytkujących reklamowane produkty. Mogą to być zarówno celebryci, jak również zwykli ludzie, których spotykamy na co dzień (sąsiadka, przyjaciel, ktoś $\mathrm{z}$ rodziny). $Z$ kolei w samych tekstach reklamowych zasada ta jest odzwierciedlona przez wykorzystywanie kwantyfikatorów ogólnych (każdy, wszyscy) oraz ilościowych, które są reprezentowane przez liczebnik nieokreślony wiele. Zastosowanie takich leksemów sprawia, że w odbiorcach przekazu reklamowego rodzi się postawa konformistyczna, bo skoro większość osób postępuje w określony sposób, to znaczy, że takie zachowanie jest poprawne. Można przytoczyć tu słowa Marka Leary'ego, który uważa, że „Ludzie często podążają za tłumem z obawy, że w przeciwnym wypadku zostaną źle ocenieni. Ponieważ jednostki, które nie podporządkują się normom obowiązującym w grupie, nierzadko zostają odrzucone" (2000: 43). Najpopularniejszym przykładem odzwierciedlającym regułę społecznego dowodu słuszności jest np. slogan: „Wszyscy mają Mambę. Mam i ja”. Ponadto niemal w każdym tekście reklamowym można przeczytać, że: „Zaufało nam już milion klientów!” bądź „Dołącz do grona najlepszych!”;

- reguła sympatii - wzbudzanie w potencjalnym kliencie sympatii może sprawić, że z dużą łatwością i przyjemnością zgodzi się on na zakup produktu, który proponuje reklamodawca. Reguła ta najlepiej sprawdza się zatem w komunikacji bezpośredniej pomiędzy nakłaniającym a nakłanianym. Nadawca wzbudza w odbiorcy sympatię poprzez odpowiednie zachowanie (uśmiech, szacunek dla klienta, uprzejmość, gotowość pomocy) oraz nienaganny wygląd (staranny strój, podkreślający urodę makijaż, zadbane uczesanie). W aspekcie werbalnym to przede wszystkim prawienie odbiorcy komplementów;

- reguła autorytetu - jak zauważa R. Cialdini: „od dnia narodzin wszyscy jesteśmy pilnie trenowani $\mathrm{w}$ posłuszeństwie wobec autorytetów i umacniani w wierze, że przeciwstawianie się im jest rzeczą złą" (2004: 192). Autorytetem może być osoba, która ma znacznie większą wiedzę od nas bądź w jakiejś kwestii nam imponuje. Dla dziecka są to najczęściej rodzice, a dla osoby dorosłej - pracodawcy bądź eksperci w konkretnej dziedzinie. Ponieważ uleganie autorytetom jest czymś powszechnym i naturalnym, regułę tę często wykorzystuje się w reklamie. Łatwiej bowiem uwierzyć odbiorcy w słowa lekarza, który wypowiada się na temat leku niż osobie, która nie jest żadnym ekspertem w dziedzinie medycyny czy farmacji. Należy jednak zastanowić się nad tym, czy prezentowane w reklamie osoby rzeczywiście są tymi, za które się podają, czy może tylko aktorami przebranymi za lekarza, dietetyka bądź kucharza;

- reguła niedostępności - reguła ta mówi o tym, że atrakcyjniejsze jest zawsze to, co trudniej można zdobyć. Stąd słabość każdego do jednorazowych 
i szybko przemijających okazji. By zatem podnieść wartość reklamowanego produktu, nadawca często informuje odbiorcę, że „liczba miejsc jest ograniczona”, ,oferta ważna tylko jeden dzień”, ,jedyna szansa na zakup...”, ,zostały już tylko 3 produkty” czy „ostatni moment, by wziąć udział w...”.

Oprócz wymienionych technik wywierania wpływu społecznego warto również wspomnieć o środkach językowych, dzięki którym nadawca w taki sposób wpływa na odbiorcę, że ten często nie zdaje sobie z tego sprawy. Dla Jadwigi Puzyniny (1992) są to:

- środki językowe, dzięki którym tekst jest przyjemny w odbiorze. Można więc tu wyróżnić wszelkie ozdobniki stylistyczne (rymy, paralelizmy, peryfrazy, metonimie czy metafory), a także całą stronę audialno-wizualną reklam (ozdobna czcionka, odpowiednia kolorystyka, charakterystyczny dźwięk). Badaczka bowiem zwraca uwagę na to, iż „właściwa tym środkom funkcja poetycka, skupiająca uwagę odbiorcy na samej formie tekstu, osłabia reakcje intelektualne odbiorcy, stanowi o ograniczeniu jego krytycyzmu" (Puzynina 1992: 219);

- środki językowe, za pomocą których nadawca w niejawny sposób przekazuje odbiorcy te treści, na których mu najbardziej zależy. Są to więc: wyrazy nieostre znaczeniowo (wspomniane wyżej kwantyfikatory), wieloznaczne struktury gramatyczne (choćby stosowanie wieloznacznych wykładników modalnych) czy struktury uniemożliwiające negację (presupozycje, np.: „Za co kobiety na całym świecie kochają produkt X?”).

Analiza tekstów reklamowych pod kątem perswazyjnych i manipulacyjnych środków językowych byłaby dobrym materiałem na obszerną monografię, nie zaś na krótki artykuł charakteryzujący różnorodne aspekty przekazu reklamowego. W podsumowaniu tego opracowania można stwierdzić, że nadawca, przekonując odbiorcę do zakupu określonego produktu, posługuje się głównie technikami manipulacyjnymi. Rzadko bowiem w tekstach reklamowych można spotkać rzeczową i uczciwą informację. Reklama „manipuluje udawaniem. Udawaniem, że jest prawdziwym, rzetelnym i weryfikowalnym komunikatem [...]” (Bralczyk 2000: 51).

Reklama jest komunikatem docierającym do szerokiego grona odbiorców. Nie oznacza to jednak, że jest naprawdę skutecznym środkiem promocji. Jak pokazują badania przeprowadzone przez CBOS w 2011 r., zdecydowana większość badanych uważa, że reklamy ich drażnią i nudzą (80\%). Jedynie co ósmy respondent upatruje w nich formy odprężenia i rozrywki (13\%). Znamienne, że te same pytania zadawane były w ankietach CBOS-u od początku lat 90. XX w., a uzyskiwane w nich odpowiedzi świadczą o coraz bardziej negatywnym stosunku Polaków do reklam. Dość powiedzieć, że w pierwszym badaniu, przeprowadzonym przez CBOS w 1992 r., większość respondentów 
odpowiedziała, że reklamy budzą ich zainteresowanie (49\%), są zachęcające (54\%) i dobrze informują o produktach $(58 \%)^{25}$. Niewątpliwie na rosnące zniechęcenie badanych wpływa fakt, że konsumenci coraz bardziej czują się przymuszani do kontaktu z reklamami, często wręcz nie mają możliwości uniknięcia ich oglądania czy słuchania. Warto jednak zadać sobie pytanie, czy reklamy, które docierają do konsumentów za pośrednictwem różnych kanałów, rzeczywiście są przygotowane w sposób przemyślany, staranny, zorientowany na wzbudzenie zainteresowania odbiorców. Wszak żadna marka nie jest w stanie zaistnieć bez dobrej reklamy, a dobra reklama to reklama skuteczna, właściwie przygotowana, o wysokiej jakości wykonania.

\section{Bibliografia}

Albin K. (2002), Reklama. Przekaz, odbiór, interpretacja, Warszawa-Wrocław.

Awdiejew A. (2004), Systemowe środki perswazji, [w:] P. Krzyżanowski, P. Nowak (red.), Manipulacja wjęzyku, Lublin, s. 71-78.

Barańczak S. (1983), Czytelnik ubezwtasnowolniony. Perswazja w masowej kulturze PRL, Paryż.

Batko A. (2005), Sztuka perswazji, czyli język wptywu i manipulacji, Gliwice.

Bralczyk J. (1996), Jezyk na sprzedaż, Warszawa.

Bralczyk J. (2000), Manipulacja językowa, [w:] Z. Bauer, E. Chudziński (red.), Dziennikarstwo $i$ świat mediów, Kraków, s. 244-250.

Cialdini R. (2004), Wywieranie wptywu na ludzi. Teoria i praktyka, Gdańsk.

Drzycimski A. (2000), Komunikatorzy: wplyw, wrażenie, wizerunek, Warszawa-Bydgoszcz.

Habrajska G. (2005), Naktanianie, perswazja, manipulacja językowa, „Acta Universitatis Lodziensis. Folia Litteraria Polonica” nr 7, t. 2, red. B. Bogołębska, M. Woźniak-Łabieniec, s. 91-121.

Jacobson R. (1989), Poetyka w świetle językoznawstwa, [w:] R. Jacobson, W poszukiwaniu istoty jezzyka. Wybór pism, t. 2, red. M. R. Mayenowa, Warszawa.

Kall J. (1995), Reklama, Warszawa.

Kamińska-Szmaj I. (2003), Perswazja w tekstach reklamowych - spojrzenie językoznawcy, [w:] M. Mosiołek-Kłosińska, T. Zgółka (red.), Jezyk perswazji publicznej, Poznań, s. 77-79.

Kamińska-Szmaj I. (2004), Propaganda, perswazja, manipulacja - próba uporządkowania pojeć, [w:] P. Krzyżanowski, P. Nowak (red.), Manipulacja w języku, Lublin, s. 13-27.

Karwat M. (1999), Sztuka manipulacji politycznej, Toruń.

Kita M. (2004), Czy można nie manipulować? O audiowizualnej retoryce w dyskursie politycznym, [w:] P. Krzyżanowski, P. Nowak (red.), Manipulacja w jezzyku, Lublin, s. 199-210.

Kołodziej J. (2002), Slogan jako definiens. O perswazyjności przekazu reklamowego, [w:] E. Żarnecka-Biały, I. Trzcieniecka-Schneider (red.), Komunikaty i argumenty, Kraków, s. 97-107.

${ }^{25}$ Obecnie tylko $19 \%$ badanych uważa reklamy za wartościowy środek informacji o artykułach i usługach. Patrz: www.cbos.pl/SPISKOM.POL/2011/K_016_11.PDF. 
Kopertowska D. (2000), Język tekstów perswazyjnych, [w:] K. Michalewski (red.), Regulacyjna funkcja tekstów, Łódź, s. 231-237.

Korolko M. (2003), Przekonuj i daj się przekonać, Piotrków Trybunalski.

Krzyżanowski P. (2004), Manipulacja w języku. Manipulacja w tekście, [w:] P. Krzyżanowski, P. Nowak (red.), Manipulacja w języku, Lublin, s. 277-282.

Kubaszewska W., Hermanowski M. (2008), Reklama w radiu, [w:] W. Kubaszewska, M. Hermanowski, Radio - bistoria i wspótczesnośc, Poznań, s. 143-194.

Kudra B., Sokół A. (2008), Perswazja w tekstach promujacych produkty firmy Coats Polska Sp. z o. o., [w:] K. Michalewski (red.), Język w marketingu, Łódź, s. 365-373.

Kudrowie A. i B. (2004), Między manipulacja a perswazja (o funkcjonowaniu antroponimów w tekście prasowym), [w:] P. Krzyżanowski, P. Nowak (red.), Manipulacja w języku, Lublin, s. 91-99.

Kuśmierski S. (2000), Reklama jest sztuka, Warszawa.

Kwarciak B. (1997), Co trzeba wiedzieć o reklamie, Kraków.

Leary M. (2000), Wywieranie wrażenia na innych. O sztuce autoprezentacji, Gdańsk.

Lewicki A., Nowak P. (2000), Manipulacja językowa w mediach, [w:] J. Bralczyk, K. Mosiołek-Kłosińska (red.), Jezzyk w mediach masowych, Warszawa, s. 34-42.

Lewiński P. (1999), Retoryka reklamy, Wrocław.

Lewiński P. (2001), Granice perswazji, [w:] G. Habrajska (red.), Język w komunikacji, t. 1, Łódź, s. 285-293.

Lubaś W. (2006), Język w komunikacji, w perswazji i w reklamie, Wyższa Szkoła Biznesu w Dąbrowie Górniczej.

Michalewski K. (1999), Przytaczanie cudzych wypowiedzi jako środek perswazji w telewizji, „Rozprawy Komisji Językowej Łódzkiego Towarzystwa Naukowego”, t. XLIV, s. 63-69.

Michalewski K. (2004), Telewizyjna manipulacja zespolona, [w:] P. Krzyżanowski, P. Nowak (red.), Manipulacja w języku, Lublin, s. 187-197.

Mosiołek-Kłosińska M., Zgółka T. (red.) (2003), Język perswazji publicznej, Poznań.

Nowak P. (2004), Parafrazowanie - narzędzie manipulacji i perswazji, [w:] P. Krzyżanowski, P. Nowak (red.), Manipulacja w jezzyku, Lublin, s. 137-150.

Piechota M., Stachyra G., Nowak P. (2012), Rozrywka w mediach i komunikacji spotecznej. Wybrane zagadnienia, Lublin.

Pisarek W. (2003), Perswazja-jakja widzq, jakjapiszq, [w:] K. Mosiołek-Kłosińska, T. Zgółka (red.), Język perswazji publicznej, Poznań, s. 9-17.

Pitrus A. (2001), Zrozumieć reklamę, Kraków.

Puzynina J. (1992), Stowo „manipulacja” w języku polskim, [w:] J. Puzynina, Język wartości, Warszawa, s. 203-223.

Sarelo Z. (2000), Podstawy etycznej oceny reklam, [w:] Sarelo Z., Media w stużbie osoby. Etyka spotecznego komunikowania, Toruń, s. 151-169.

Szkudlarek-Śmiechowicz E. (2007), Niewerbalne środki komunikacji a moc perswazyjna wypowiedzi, [w:] G. Habrajska, A. Obrębska (red.), Mechanizmy perswazji i manipulacji, Łódź, s. 299-307.

Szulc M. (2000), Technologia prasy, [w:] Z. Bauer, E. Chudziński (red.), Dziennikarstwo i świat mediów, Kraków.

Tokarski R. (2004), Semantyka barw we wspótczesnej polszczyźnie, Lublin.

Tokarz M. (2006), Argumentacja, perswazja, manipulacja, Gdańsk.

Warchala J. (2004), Horyzonty manipulacji: perswazja, manipulacja, interpretacja, [w:] P. Krzyżanowski, P. Nowak (red.), Manipulacja w jezyku, Lublin, s. 41-60. 
Wiśniewska A., Miczmańska K. (2011), Wykorzystanie postaci jako instrumentu perswazji w reklamie, „Roczniki Ekonomiczne Kujawsko-Pomorskiej Szkoły Wyższej w Bydgoszczy”, nr 4 [Bydgoszcz].

Zimny R. (2008), Kreowanie obrazów świata w tekstach reklamowych, Warszawa.

Żarnecka-Biały E., Trzcieniecka-Schneider I. (red.) (2002), Komunikaty i argumenty, Kraków.

\section{Netografia}

http://kadry.nf.pl/Artykul/13730/Slogany-firmowe-Wspracie-wyroznienia-marki-firmy/marka-firmy-misja-firmy-slogany-firmowe-wizja-firmy.

www.cbos.p1/SPISKOM.POL/2011/K_016_11.PDF. 